\title{
PENGGUNAAN ANALOGI DALAM PEMBELAJARAN FISIKA MELALUI METODE EKSPERIMEN TOPIK ALIRAN ARUS LISTRIK UNTUK MENINGKATKAN PENGUASAAN KONSEP SISWA KELAS X SMA YPPK TARUNA DHARMA KOTARAJA
}

\author{
Silvia Apriliani ${ }^{1}$, Indah Slamet Budiarti ${ }^{2}$, Albert Lumbu ${ }^{3}$ \\ ${ }^{1,2,3}$ Prodi Pendidikan Fisika Jurusa FMIPA \\ ${ }^{1,2,3}$ Universitas Cendrawasih
}

\begin{abstract}
ABSTRAK
Tujuan penelitian ini adalah : (1) untuk meningkatkan penguasaan konsep siswa dengan pembelajaran analogi (2) untuk mengetahui perbedaan penguasaan konsep siswa antara kelompok kelas yang diberi perlakuan dengan menggunakan model analogi metode eksperimen dan kelompok kelas yang diberi perlakuan dengan menggunakan metode ceramah. Populasi dalam penelitian ini adalah seluruh siswa kelas X SMA YPPK TARUNA DHARMA Kotaraja, sedangkan sampel yang diambil dalam penelitian ini adalah siswa kelas X2 sebanyak 20 subjek sebagai kelas eksperimen dan kelas X3 sebanyak 17 subjek sebagai kelas kontrol. Penelitian yang dilaksanakan merupakan penelitian kuasi dengan rancangan nonequivalent control group design. Untuk mengetahui tingkat perbedaan penguasaan konsep siswa antara penggunaan model analogi metode eksperimen dan penggunaan metode ceramah digunakan uji beda (uji Mann Whitney), dan hasil yang diperoleh yaitu $U$ hitung < $U$ tabel atau $0<93$. Hal ini menunjukkan bahwa terdapat perbedaan antara penggunaan model analogi metode eksperimen dan penggunaan metode ceramah.
\end{abstract}

Kata kunci : Model analogi, metode eksperimen, penguasaan konsep siswa

\section{PENDAHULUAN}

Dalam dunia pendidikan sudah pasti didalamnya terdapat suatu proses belajar mengajar yang dilakukan oleh seorang guru terhadap siswa. Dalam proses belajar mengajar di sekolah sering dijumpai kesulitan-kesulitan yang dialami guru dan siswa, terutama dialami oleh guru IPA. Kesulitan-kesulitan tersebut salah satunya adalah dalam memberikan penjelasan atau pemahaman suatu peristiwa tertentu yang ada di dalam materi pengajaran kepada siswa. Untuk memberikan pemahaman yang lebih baik kepada siswa, maka diperlukan penjelasan-penjelasan konsep yang dapat dengan mudah dipahami oleh siswa. Jika materi yang diajarkan berhubungan dengan ranah di luar jangkauan panca indera manusia ataupun alat bantu untuk pengamatan, sudah pasti seorang guru atau pengajar akan megalami kesulitan dalam memberikan penjelasan.
Oleh sebab itu, diperlukan suatu cara-cara tertentu untuk mengatasi kesulitan-kesulitan tersebut. Cara-cara untuk mengatasi kesulitan-kesulitan dalam proses belajar mengajar haruslah dimiliki oleh seorang guru, ini bertujuan untuk membantu guru menyelesaikan tugasnya.

Melalui proses belajar mengajar guru harus mampu mengetahui kesulitan yang dialami siswa dan mencari alternatif pemecahannya. Sedangkan sebagai perencana pengajaran, guru diharapkan mampu merencanakan kegiatan belajar mengajar secara efektif. Salah satu alternatif yang dapat membuat pembelajaran IPA, khususnya Fisika lebih menarik dan siswa dapat berperan aktif adalah menerapkan berbagai metode pembelajaran yang disesuaikan dengan materi yang hendak disampaikan. Proses belajar dalam kelas sering kali mengalami gangguan, salah satunya berasal dari faktor lingkungan. Beberapa faktor lingkungan 
tersebut antara lain yaitu: (1) jumlah siswa yang terlalu banyak mengakibatkan guru kesulitan memantau seluruh siswa; (2) kurang tersedianya buku-buku paket/pegangan sebagai sumber bahan ajar; (3) kondisi ruang dan prasarananya yang kurang memadai.

Dalam materi ajar Fisika, khususnya materi aliran arus listrik terdapat beberapa kesulitan atau permasalahan yang dapat dialami guru, salah satunya dalam memberikan pemahaman konsep mengenai arah arus listrik dan beda potensial atau beda tegangan. Pemahaman materi tersebut sedikit lebih sulit karena sifatnya yang abstrak, tidak dapat diamati dengan alat indera manusia. Jika pemahaman yang diterima atau yang dikuasai siswa rendah, maka dapat dimungkinkan terjadinya miskonsepsi atau salah persepsi dalam materi ajar ini. Untuk mengantisipasi hal ini, maka seorang guru diharapkan mampu mencari solusi dalam penyelesaian masalah ini. Solusi yang dapat diberikan dalam kesulitan atau permasalahan tersebut, salah satunya adalah dengan meningkatkan pemahaman konsep siswa dalam materi ajar. Untuk meningkatkan pemahaman konsep siswa, salah satunya adalah dapat dengan menggunakan model pembelajaran analogi metode eksperimen.

Metode pembelajaran yang dapat digunakan dalam proses belajar mengajar ada banyak metode. Salah satunya adalah metode eksperimen atau laboratorium. Metode eksperimen (Paul Suparno 2007:77) adalah metode mengajar yang mengajak siswa untuk melakukan percobaan sebagai pembuktian, pengecekan bahwa teori yang sudah dibicarakan itu memang benar. Biasanya metode eksperimen bukan untuk menemukan teori, tetapi lebih untuk menguji teori atau hukum yang sudah ditemukan para ahli. Namun dalam prakteknya di lapangan, metode ini dapat dimodifikasi. Salah satunya adalah yang akan diteliti dalam penelitian ini, yaitu menggunakan analogi dalam pembelajaran Fisika melalui metode eksperimen.

Penelitian ini dipilih karena peneliti merasa bahwa model analogi dengan metode eksperimen ini dapat membantu dalam memberikan peningkatan pemahaman konsep yang lebih baik terhadap siswa. Model analogi dengan metode eksperimen ini juga mampu membantu siswa memahami materi ajar yang pemahamannya di luar jangkauan ranah pancaindera manusia yang juga tidak ada alat bantu lain untuk dilakukan pengamatan terhadap materi tersebut. Model analogi dengan metode eksperimen membantu menjelaskan konsep dengan memadankannya dengan suatu peristiwa yang ada disekitar dan dapat dengan mudah ditemui serta diamati. Dan dalam penerapannya dilakukan secara eksperimen. Disini, model dengan metode ini sangat cocok pada materi ajar aliran arus listrik. Dimana, aliran arus listrik tidak dapat diamati dengan alat indera sehingga dapat dianalogikan dengan aliran arus air yang dapat secara langsung diamati dan mudah ditemui disekitar manusia.

Model analogi dengan metode eksperimen dalam pengembangannya mensyaratkan adanya kemiripan alur berpikir, yaitu kemiripan alur berpikir pada konsep target analogi berupa materi ajar aliran arus listrik dan konsep rujukan berupa materi ajar aliran arus air. Untuk menjelaskan konsep target analogi, maka diperlukan sebuah konsep rujukan, yang nanti pada akhirnya akan menjadi sebuah pembanding dalam pencapaian hasil belajar siswa. Jika pada konsep rujukan dan konsep target terdapat banyak kesamaan atau kemiripan, maka sebuah analogi berpikir dapat dibangun. Meskipun model pengajaran sains dengan analogi diyakini dapat mempermudah proses belajar mengajar siswa, namun penerapan teknik ini di kelas harus memperhatikan beberapa hal, misalnya prakonsepsi dan daya serap siswa untuk menghindari terjadinya miskonsepsi. Untuk diketahui, salah satu hal yang penting dan perlu digaris bawahi dalam model ini adalah konsep materi ajar yang telah dijadikan bahan rujukan analogi diasumsikan telah diajarkan terlebih dahulu sebelum konsep materi ajar yang dijadikan sebagai target analogi.

$\mathrm{Hal}$ inilah yang mendorong penulis untuk mengambil judul penelitian "Penggunaan Model Analogi dalam Pembelajaran Fisika Melalui Metode 
JPFK, Volume 1, Nomor 1, Maret 2015 : 14 - 19

Eksperimen Topik Aliran Arus Listrik Untuk Meningkatkan penguasaan Konsep Siswa".

\section{METODOLOGI PENELITIAN}

Penelitian yang dilaksanakan merupakan penelitian kuasi dengan rancangan nonequivalent control group design. Instrumen yang digunakan pada penelitian ini terdiri dari tes keterampilan penguasaan konsep fisika (pretest dan posttest) dan angket. Gain skor ternormalisasi (g) setiap siswa baik pada kelas kontrol maupun kelas eksperimen dihitung berdasarkan skor pretest dan posttest, serta skor maksimum ideal.

Uji beda yang digunakan adalah $\mathrm{t}$ test (jika data berdistribusi normal dan varians antar kelompok homogen) atau uji Mann Whitney (jika data tidak berdistribusi normal dan varians antar kelompok tidak homogen). Uji beda menggunakan taraf signifikansi $5 \%$. Ho ditolak jika nilai signifikan $<0,05$ (nilai $\alpha$ ).

Pengambilan sampel dapat dilakukan dengan menggunakan teknik purposive sampling.Pola Desain Penelitian
Tabel 1. Desain Penelitian

\begin{tabular}{clccc}
\hline No & $\begin{array}{c}\text { Kelompok } \\
\text { Kelas }\end{array}$ & $\begin{array}{c}\text { Pretes } \\
\text { t }\end{array}$ & $\begin{array}{c}\text { Metod } \\
\text { e }\end{array}$ & $\begin{array}{c}\text { Postes } \\
\text { t }\end{array}$ \\
\hline 1. & $\begin{array}{l}\text { Eksperime } \\
\mathrm{n}\end{array}$ & 0 & $\mathrm{X}_{1}$ & 0 \\
\hline 2. & Kontrol & 0 & $\mathrm{X}_{2}$ & $0^{\prime}$ \\
\hline
\end{tabular}

\section{HASIL DAN PEMBAHASAN \\ Pengujian Normalitas Data Angket kelas Eksperimen}

Setelah diadakan pengujian dengan menggunakan Rumus Chi-Kuadrat, maka data angket, pretes dan postes baik kelas kontrol maupun kelas eksperimen tidak terdistribusi normal, sehingga analisis uji beda menggunakan uji mannwhitney

\section{Analisis Data \\ Angket}

Data angket merupakan data penunjang terhadap data tes penguasaan konsep. Berdasarkan data angket diperoleh presentase sebagai berikut.

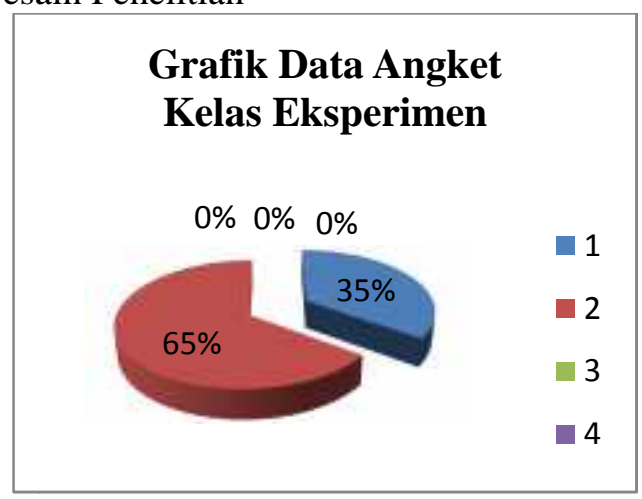

Gambar 1. Grafik angket Kelas Eksperimen

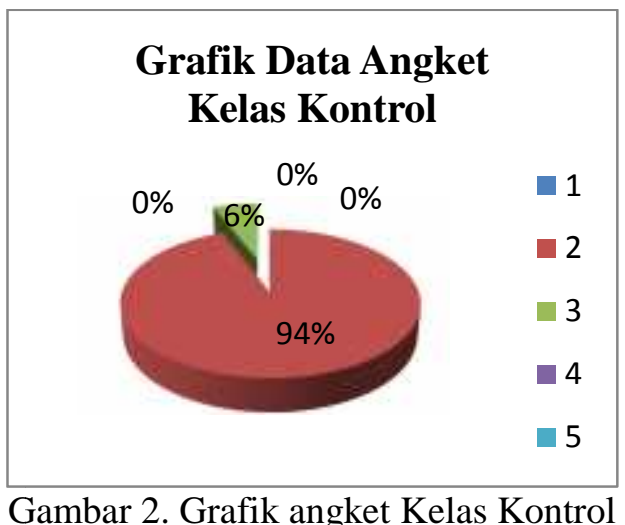



Berdasarkan data tersebut di atas maka dapat diambil kesimpulan bahwa terdapat perbedaan presentase antara kelompok kelas eksperimen dan kelompok kelas kontrol. Pada kelompok kelas eksperimen presentase siswa yang senang dengan metode dan model pembelajaran lebih tinggi jika dibandingkan dengan kelompok kelas kontrol $(78 \%>67 \%)$.

\section{Tes Penguasaan Konsep}

Dari hasil perhitungan uji beda (Uji Mann Whitney) diperoleh U hitung $=0$. Berdasarkan tabel harga-harga kritis Mann-Whitney U Test dengan $\alpha=$ 0,05 dengan $\mathrm{n} 1=17$ dan $\mathrm{n} 2=20$ diperoleh harga $\mathrm{U}$ tabel $=93$. Ternyata harga $\mathrm{U}$ hitung lebih kecil dari $\mathrm{U}$ tabel $(0<93)$. Dengan demikian keputusan yang diambil adalah Ho di tolak dan Ha diterima.

\section{Hasil Analisis Penilaian Aspek Kognitif}

Tabel 2. Data Gain Kelas Eksperimen

\begin{tabular}{llc}
\hline No. & \multicolumn{1}{c}{ Kategori gain } & $\begin{array}{c}\text { Presentase } \\
\text { gain }\end{array}$ \\
\hline 1. & $\begin{array}{l}\text { Penguasaan } \\
\text { tinggi }(\mathrm{g}>0,7)\end{array}$ & $40 \%$ \\
2. & $\begin{array}{l}\text { Penguasaan } \\
\text { sedang }(0,3 \leq \mathrm{g} \leq 0,7)\end{array}$ & $60 \%$ \\
3. & $\begin{array}{l}\text { Penguasaan konsep } \\
\text { rendah }(\mathrm{g}<0,3)\end{array}$ \\
\hline
\end{tabular}

Tabel 3. Data Gain Kelas Kontrol

\begin{tabular}{llc}
\hline No. & \multicolumn{1}{c}{ Kategori gain } & $\begin{array}{c}\text { Presentase } \\
\text { gain }\end{array}$ \\
\hline $1 . \quad \begin{array}{l}\text { Penguasaan konsep tinggi }(\mathrm{g} \\
>0,7)\end{array}$ & $0 \%$ \\
2. $\quad \begin{array}{l}\text { Penguasaan konsep sedang } \\
(0,3 \leq \mathrm{g} \leq 0,7)\end{array}$ & $60 \%$ \\
3. & $\begin{array}{l}\text { Penguasaan konsep rendah } \\
(\mathrm{g}<0,3)\end{array}$ \\
\hline
\end{tabular}

\section{Pembahasan Hasil Penelitian}

Perbedaan tingkat penguasaan konsep siswa dapat dilihat berdasarkan data penilaian aspek kognitif. Peningkatan penguasaan konsep antara nilai pretes dan postes pada kelas eksperimen lebih tinggi jika dibandingkan dengan kelas kontrol. Perbedaan tingkat penguasaan konsep siswa tersebut dipengaruhi oleh beberapa faktor, beberapa diantaranya adalah faktor model dan metode pembelajaran yang digunakan.

Secara umum model pembelajaran analogi adalah model pembelajaran penjelasan suatu konsep atau topik dengan cara menganalogikan dengan suatu peristiwa yang mudah dimengerti siswa. Banyak guru Fisika menggunakan model ini untuk menjelaskan konsep Fisika yang sulit dan abstrak. Dengan menggunakan model pembelajaran ini dalam topik aliran arus listrik, siswa dituntun untuk memahami dengan konsep yang lebih sederhana dan dapat diamati secara langsung dalam keseharian siswa sehingga konsep target akan mudah tercapai. Dengan menggunakan model pembelajaran ini kemampuan imajinasi siswa akan meningkat. Metode eksperimen adalah metode mengajar yang mengajak siswa untuk melakukan percobaan melalui pembuktian, pengecekan bahwa teori yang dipelajari itu memang benar (Paul Suparno 2007:77). Jadi metode ini lebih untuk mengecek supaya siswa semakin yakin dan jelas akan teori atau hukum yang sudah ditemukan para ahli. Dengan menggunakan metode pembelajaran ini maka siswa akan semakin memahami konsep teori yang diajarkan dan siswa dibantu aktif belajar, sedangkan dengan menggunakan metode ceramah siswa dimungkinkan kurang memahami teori dan kurang melibatkan seluruh pancaindera siswa sehingga siswa akan kurang mengembangkan kreatifitasnya. Hal ini dapat menyebabkan konsep target sulit tercapai.

Pada topik aliran arus listrik sangat tepat jika menggunakan model pembelajaran analogi, karena akan menuntun siswa untuk berfikir secara abstrak. Arus listrik pada sebuah kawat penghantar tidak dapat diamati dengan menggunakan mata, tetapi jika dianalogikan dengan aliran arus air yang sering diamati dalam kehidupan sehari-hari maka siswa akan lebih mudah untuk memahami konsepnya. Meskipun begitu ada beberapa hal yang perlu untuk lebih diberi penekanan dalam penerapan pembelajaran dengan model analogi, yaitu dalam pemilihan analogi dan perbedaan antara konsep yang sesungguhnya dari peristiwa Fisika yang dipelajari dengan analogi atau gambaran yang digunakan. Jika analogi yang digunakan atau dipilih tidak dikenali oleh siswa, seringkali pembelajaran akan menjadi tidak efektif. 
Begitu pula jika siswa tidak dapat membedakan antara konsep yang sesungguhnya dengan konsep yang dianalogikan, hal ini dapat menimbulkan miskonsepsi. Tetapi jika terjadi hal demikian maka dapat dibantu dengan menggunakan analogi penghubung.

\section{PENUTUP}

Kesimpulan

Berdasarkan hasil penelitian yang diperoleh dan pembahasan yang diuraikan sebelumnya, penulis menyimpulkan :

1. Terdapat perbedaan penguasaan konsep antara model pembelajaran analogi dengan metode eksperimen dan model konvensional dengan metode ceramah

2. Pembelajaran model analogi dengan metode eksperimen dapat meningkatkan penguasaan konsep siswa.

\section{DAFTAR PUSTAKA}

Edi Istiyono. 2004. Sains Fisika untuk Kelas $\boldsymbol{X}$ Jilid Ib. Klaten : Intan Pariwara

Edi Hendri Mulyana. 2005. Asesmen dalam Pembelajaran Sains SD. [Online] (http://assesmenpembelajaranSD_g oogle.com) diakses pada tanggal: 08 Nopember 2011

Fakultas Keguruan dan Ilmu Pendidikan. 2001. Pedoman Penulisan Skripsi dan Makalah FKIP Universitas Cenderawasih. Jayapura : Universitas Cenderawasih

Ferdi. 2011. Pengertian Belajar dan Pembelajaran. [Online] (http://definisi belajar_google.com) diakses pada tanggal: 19 Nopember 2011

Hake, Richard. R. 2002. Relationship of Individual Student Normalized Learning Gains in Mechanics with Gender, High School Physics, and Pretest Scores on Mathematics and Spatial Visualization. [Online] (http://www.arxiv.org) diakses pada tanggal 11 Juli 2012

Hake, Richard. R. 2008. InteractiveEngagement Versus Traditional Methods: A Six-Thousand-Student Survey of Mechanics Test Data for Introductory Physics Course. American Journal of Physics. [Online]

(http://www.physics.indiana.edu/ h ake) diakses pada tanggal : 5 Juli 2012

Hardiyawan Indrayanto. 2007. Perbandingan Kemampuan Berpikir Kreatif Siswa Sekolah Menengah Atas antara Siswa yang Memperoleh Pembelajaran Matematika Melalui Pendekatan Bridging Analogy dengan Pendekatan Biasa. [Online] (Http://digilib.upi.edu/pasca/availab le/etd-0523107-100950/) diakses pada tanggal: 28 Nopember 2011

Paul Suparno. 2007. Metodologi Pembelajaran Fisika. Yogyakarta : Universitas Sanata Dharma

Ridwan. 2009. Metode dan Teknik Menyusun Proposal Penelitian. Bandung : Alfabeta

Riduwan. 2010. Metode dan Teknik Menyusun Tesis. Bandung : Alfabeta

Sudjana. 2005. Metoda Statistika edisi 6. Bandung : Tarsito

Sugiyono. 1999. Statistika untuk penelitian. Bandung : Alfabeta

Sugiyono. 2010. Metode Penelitian Pendidikan. Bandung: Alfabeta

Suharsimi Arikunto.( 2002). Prosedur penelitian Suatu Pendekatan Praktek edisi revisi V. Jakarta : Rineka Jaya

Sparisoma Viridi. 2010. Pembelajaran Fisika: Asumsi Tersembunyi, 
JPFK, Volume 1, Nomor 1, Maret 2015 : 14 - 19

Miskonsepsi, Cara Belajar Analogi, Peraga - Eksperimen Sederhana, dan Muatan Lokal. [Online]

(http://www.google.com/pembelaja ran-fisika-metode-analogi/) diakses pada tanggal: 28 Nopember 2011

Tjipto Prastowo. 2011. Jurnal Penelitian Fisika dan aplikasinya. [Online] (http://www.scholar.google.com/tji pto_prastowo/2011/02/jurnal-

penelitian -fisika-dan-aplikasinya/) diakses pada tanggal : 8 September 2011
Wikipedia. Filosofi Pendidikan. [Online] (http://dasarpendidikan.wikipedia.c om) diakses pada tanggal : 28 Nopember 2011 